\title{
Dental education - shaping the future
}
IN BRIEF
- Considering how we deliver dental education may alter the fate of the dental profession and those in it, and is therefore well worth doing.
- Moving away from an authoritarian approach to dental education will help to develop a profession that influences the political view of what is 'best'.

E. Kay ${ }^{1}$

\footnotetext{
Education is key to shaping the future of the dental profession and careful thought must be given to the direction dental education is heading and whether it still allows for the necessary development and innovation that will lead the profession forth and raise it up.
}

Etymologically the word 'education' stems from the Latin word e-ducate - to lead forth, to raise up. We need to consider very carefully whether our current dental education system, and the way it is regulated, still allows dental education to continue to lead the profession forth and raise it up. For dentistry is standing at a 'fork in the path' of its own destiny. The choices made now will seal the fate of the profession and those in it for the foreseeable future. We must therefore consider our options very carefully.

The foundation of our professional lives, and the grounding for it, begins when we enter dental school and thus, we must make sure that that crucial part of a lifetime of professional development is absolutely appropriate for the profession as we want it to be. Education is not, as some seem to think, just about teaching people things. If we care about our profession's future, we need to recognise that education is an extremely important agent of social change and therefore we need to ensure that the changes our education system brings about are beneficial to all concerned. How (rather than just what) we teach our students has a profound effect on the direction the profession of dentistry will take in the future. Therefore, taking a moment to carefully consider the part we want our dental education system to play is time well spent. The issue that we perhaps need to be most clear about is the difference between

'Foundation Dean, Peninsula Dental School, Peninsula Dental School, Plymouth University, Portland Square, Drake Circus, Plymouth, Devon, PL4 8AA

Correspondence to: Professor Elizabeth Kay

Email: elizabeth.kay@plymouth.ac.uk

\section{Refereed Paper}

Accepted 15 January 2014

DOI: 10.1038/sj.bdj.2014.298

${ }^{\circledR}$ British Dental Journal 2014; 216: 447-448 education and training, and what the future effects of choosing one or other has on the development and future intellectual growth of our profession.

\section{EDUCATION AND TRAINING ARE DIFFERENT}

When you train someone it is about ensuring that another person does things as you see fit. So training is dependent on the idea of there being a person who 'knows' and one who does not - a person in the 'right' and a person who has still to learn what is 'right'. So training is largely about creating compliant students. Indeed that is almost its entire purpose. Training doesn't necessarily create 'good' students in the sense of someone who will achieve great things, but it does create students who do things as the teacher says and who will behave as the trainer thinks best. Training results in able workers who get on with the work in the way the trainers and 'overseers' allotted to them believe they should. Well trained people accept this dominance and accept that they do not 'know' much, and that they need to be told what and how to learn. Trainees do not believe that they can bring much in the way of wisdom to the activity they are being trained in. Of course trainees will be very similar to one another once their training is complete... which is when they are considered to be sufficiently like those in authority over them! This similarity that thorough training creates between individuals means that one person can easily be replaced by another. This ensures that things continue as they always have with no-one rocking the boat. Innovation, new ideas or creativity are rare and are largely discouraged. Thus the current 'powers that be' are reinforced and maintained, and change and new directions or novel thinking become rarities that the 'establishment' largely disapproves of.

Education on the other hand encourages people to think critically about what they do and how they do it. Indeed, good education even questions why things are done in the first place. Educators are open to the student about the biases, uncertainties and unknowns contained in what is being taught. So education encourages students not just to be able to do, but to learn about how they do it and how they learn. Educators (as opposed to trainers) love questions and students who challenge. Training positively discourages questions, possibly sees such behaviour as close to insubordination. But it is willingness to accept challenges and new ideas that potentially creates new and better ways of doing things. Think of the great steps forward in dentistry that occurred when some bright, forward-thinking individual suggested that we stop doing things the way they've always been done and sought new answers.

So, by educating, instead of training, we are freeing people to challenge, criticise and reject current thinking. We are not encouraging people to the status quo but to inspired developments and new ways of approaching problems. The intention is that by educating we will create new generations of people who will help to develop the profession of dentistry. For as long as those individuals draw their drive for innovation and change from the needs of the population they serve, the profession will be led in a direction that benefits all. If, on the other hand, the profession allows itself to be locked into sameness, behaviour devoid of critical analysis will become the norm because of fears of litigation, regulatory wrath or perverse financial incentivisation This leaves the door open for the profession to be led by those who are driven by reasons 
of personal importance and power rather than the good of the public and profession.

\section{WHICH IS BEST?}

Which is best - education or training? Well, educating people into our profession means that we will have a body of people who think critically and independently and who, when it is felt to be justified, will challenge and question authority. They will develop new and innovative ways of doing things, based on original concepts and insightful thoughtfulness. Most importantly, educating properly will create professionals who are not simply passive consumers of the 'received wisdom' of their elders, who believe in the truth of what they say because it is based on authority, but people who develop a level of understanding of their profession, the people connected with it, and what it is for and what it is really about. These are the type of people who will be agents of social and scientific change.

Training means that we will have a body of people who had to learn to do a list of things in the way someone before them liked them done. Thus, the profession will be taught to keep doing the same things, in the same way, regardless of the changed world around, resulting ultimately in a profession who have a set of skills suited to the world as it was, not as it is, or will be. And in a world where change is the only certainty and the pace of change is continually accelerating, the above state of affairs will have dire consequences for professional autonomy. In such a scenario, the profession would, of necessity become increasingly regulated and controlled. However, educating means that the teachers must discuss, and allow students to challenge, the traditionally accepted assumptions. That is because education requires the seeking of truths and ways forward, and is not about power, control or authority. It would seem to me that the very best chance we have of developing a profession who will shape the future and its own destiny is for us to accept that 'knowing', (especially in healthcare) is a social process involving not just knowledge, but others' feelings and beliefs. Adopting a 'Frierian'* rather than authoritarian approach to the development of young dentists gives us the best chance of developing a profession that will 'lead' rather than 'be told' - a profession that develops, creates and influences the political view on how best to serve the population.

So, we have a choice. Which future for our profession will you choose? Or more importantly, which would the future recipients of our professions' services choose? People who can advocate, enhance, advance and innovate, or fossilised automatons reliant entirely on the attitudes of their 'overseers' to decide what is best for the profession, patients and the public at large?

*Paulo Friere was a Brazilian educator and philosopher. He said 'There is no such thing as a neutral education. Education either functions as an instrument to facilitate the integration of generations into the present system and bring conformity to it, or it becomes the 'practice of freedom' by which means men and women deal critically with reality and discover how to participate in the transformation of their world' 